\title{
TU/e EmonONEN

\section{Plasma deposited carbon films as a possible means for divertor repair}

\section{Citation for published version (APA):}

Beulens, J. J., Buuron, A. J. M., Groot, P., Bakker, J., \& Schram, D. C. (1991). Plasma deposited carbon films as a possible means for divertor repair. In Y. Tzeng (Ed.), Applications of Diamond Films and Related Materials Proceedings of the First International Conference on the Applications of Diamond Films and Related Materials ADC '91 Auburn, Alabama, U.S.A., August 17-22, 1991 (pp. 737-742). (Materials Science Monographs; Vol. 73). Elsevier. https://doi.org/10.1016/B978-0-444-89162-4.50116-0

DOI:

10.1016/B978-0-444-89162-4.50116-0

Document status and date:

Published: 01/01/1991

\section{Document Version:}

Publisher's PDF, also known as Version of Record (includes final page, issue and volume numbers)

\section{Please check the document version of this publication:}

- A submitted manuscript is the version of the article upon submission and before peer-review. There can be important differences between the submitted version and the official published version of record. People interested in the research are advised to contact the author for the final version of the publication, or visit the $\mathrm{DOI}$ to the publisher's website.

- The final author version and the galley proof are versions of the publication after peer review.

- The final published version features the final layout of the paper including the volume, issue and page numbers.

Link to publication

\section{General rights}

Copyright and moral rights for the publications made accessible in the public portal are retained by the authors and/or other copyright owners and it is a condition of accessing publications that users recognise and abide by the legal requirements associated with these rights.

- Users may download and print one copy of any publication from the public portal for the purpose of private study or research.

- You may not further distribute the material or use it for any profit-making activity or commercial gain

- You may freely distribute the URL identifying the publication in the public portal.

If the publication is distributed under the terms of Article 25fa of the Dutch Copyright Act, indicated by the "Taverne" license above, please follow below link for the End User Agreement:

www.tue.nl/taverne

Take down policy

If you believe that this document breaches copyright please contact us at:

openaccess@tue.nl

providing details and we will investigate your claim. 


\title{
PLASMA DEPOSITED CARBON FILMS AS A POSSIBLE MEANS FOR DIVERTOR REPAIR
}

\author{
J J. Beulens ${ }^{a}$, A. J. M. Buuron ${ }^{a}$, P. Groot ${ }^{b}$, J. Bakker ${ }^{b}$, and D. C. Schram ${ }^{a}$ \\ aDept. of Physics, Eindhoven University of Technology, \\ P.O. Box 513, $5600 \mathrm{MB}$ Eindhoven, The Netherlands \\ b Netherlands Energy Research Foundation, ECN, \\ P.O. Box 1, 1755 ZG Petten, The Netherlands
}

\begin{abstract}
Fast deposition of graphitic carbon layers by an expanding cascaded arc plasma has been studied as a means for in situ repair of graphite erosion damage in the next step fusion reactor NET/ITER. Amorphous graphite was produced at rates of hundreds of $\mathrm{nm} / \mathrm{s}$ on several $\mathrm{cm}^{2}$ with an argon/hydrocarbon plasma. Crystalline graphite was produced at rates of $10-50 \mathrm{~nm} / \mathrm{s}$ on several $\mathrm{cm}^{2}$ by means of an argon/hydrogen/hydrocarbon plasma. Relations between the deposition parameters, morphology (by SEM) and Raman spectra have been determined. By laser thermal shock testing, the erosion resistance of the best crystalline coatings was determined at about $2 \mathrm{MJ} / \mathrm{m}^{2}$ (in a $10 \mathrm{~ms}$ pulse).
\end{abstract}

\section{NTRODUCTION}

An issue in the next step fusion reactor NET/ITER are the plasma facing components and repair of erosion damage. In the separatrix configuration (figure 1), particularly the divertor plates are subjected to high heat loads and particle fluxes. Under normal operation they will have to accomodate a heat flux of about $15 \mathrm{MJ} / \mathrm{m}^{2}$ [1]. The surface temperature of the divertor plates has to be controlled to maximally $-1000^{\circ} \mathrm{C}$, and (self) sputtering has to be limited. Principal requirents for surface material are high thermal conductivity and consistent (e.g. crystalline) structure, and, a low atomic number. Oriented pyrolytic graphite and carbon fiber composite (CFC) are considered as suitable

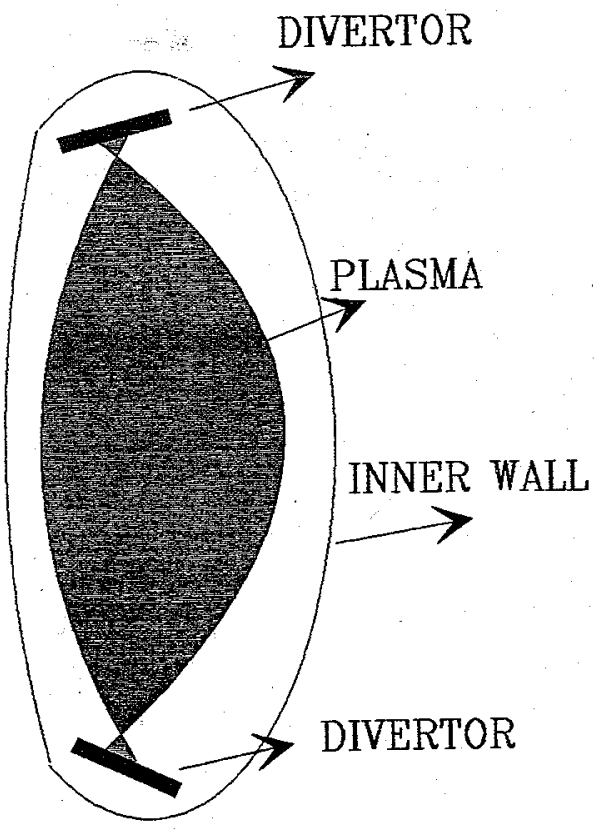

Figure 1. Outline of ITER design with divertor plates. 
candidates. Estimates for the energy dump in a disruption are $2-20 \mathrm{MJ} / \mathrm{m}^{2}$ in $0.1-3$ $\mathrm{ms}$ (thermal quench) and $2 \mathrm{MJ} / \mathrm{m}^{2}$ in $5-50 \mathrm{~ms}$ (current quench), which would result in a material loss of 0.5 to $1 \mathrm{~mm}$ on several $\mathrm{dm}^{2}$. This is a primary life time limiting factor.

In a cooperation among Eindhoven University of Technology, The Netherlands Energy Research Foundation (Petten ECN) and the Next European Torus (NET) team fast carbon deposition by an expanding cascaded arc has been studied as an option for in situ repair of erosion damage (under NET contract no. 90-237).

With this particular deposition method, in the past deposition rates of up to 200 , $\mathrm{nm} / \mathrm{s}$ for a-C:H (amorphous hydrogenated carbon) [2] and of $20 \mathrm{~nm} / \mathrm{s}$ for diamond [3] have been obtained. These rates are an order of magnitude higher than the with the conventional RF glow discharge methods.

For the present purpose the attention was focussed on the deposition of graphitic carbon. In a feasibility study the possibility of very fast deposition of nanocrystalline ('amorphous') graphite at hundreds of $\mathrm{nm} / \mathrm{s}$ by an argon hydrocarbon plasma has been demonstrated [4]. In order to optimize the crystallinity of the graphite hydrogen was admixed in the argon/hydrocarbon plasma while also other parameters were varied. The microstructure of the coatings was analyzed by SEM (Scanning Electron Microscopy) and Raman spectroscopy. At the Netherlands Energy Research Foundation disruption simulation experiments with a laser thermal shock set up [5] were carried out.

In this study direct relations between morphology, Raman spectrum and erosion resistance of the coatings on the one hand and the reactor parameters during deposition on the other hand are demonstrated. Interrelations between the results of the three diagnostics are also shown.

\section{EXPERIMENTAL CONFIGURATION}

In figure 2. an outline of the expanding cascaded arc set up is shown. The main feature of the method is the separation of the three functions production, transport, and deposition. Principal advantages of this method as compared to the conventional ones are high growth rates by the active particle transport towards the substrate, and flexibility in handling arc and substrate parameters. $\AA$ cascaded arc plasma (4 $\mathrm{mm}$ diameter, 6 $\mathrm{cm}$ length), expanding in a vacuum chamber is used as a particle source. Specific features of this source are high power dissipation (about $5 \mathrm{~kW}$ ), thermal plasma (temperatures $-1 \mathrm{eV}$ ) and, very long times of continuous operation (days). The carrier gas argon is injected at the beginning of the arc channel (flow rate $100 \mathrm{cc} / \mathrm{s}$ ), at a pressure in the order of $10^{5} \mathrm{~Pa}$. The ionization degree is typically about $10 \%$, rendering an electron density in the order of $10^{22} / \mathrm{m}^{3}$. As a

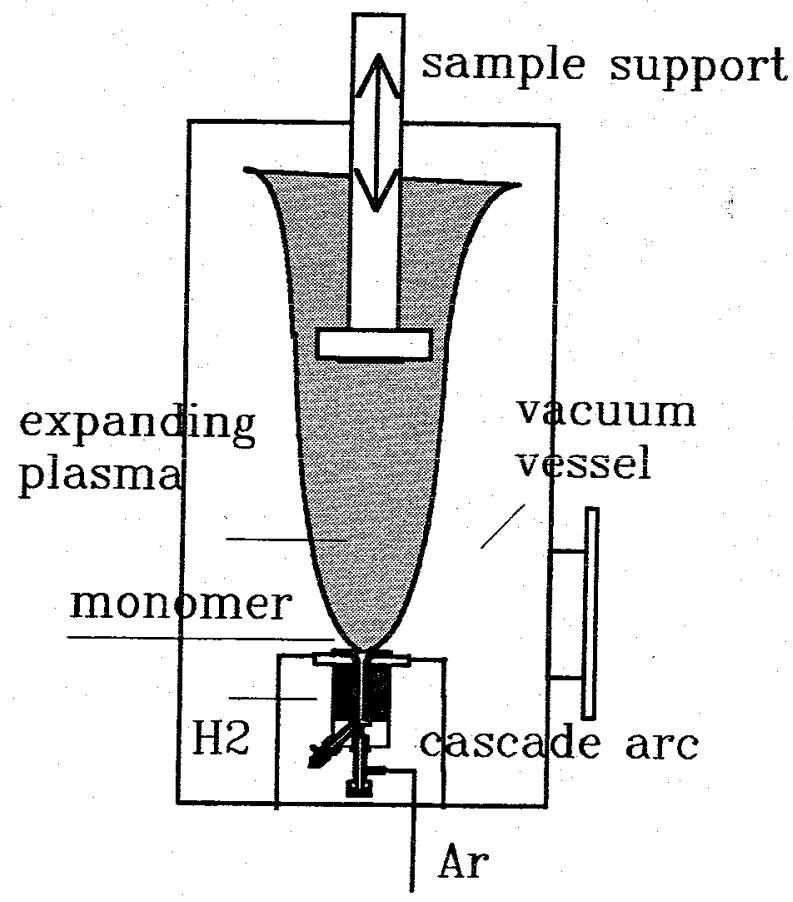

Figure 2. Outline of the expanding cascaded arc set up. 
consequence the arc plasma is close to LTE. A hydrocarbon $\left(\mathrm{CH}_{4}\right.$ or $\left.\mathrm{C}_{2} \mathrm{H}_{2}\right)$ can be injected (at rates of 0.1 to $10 \mathrm{cc} / \mathrm{s}$ ) at the end of the arc channel. As an etching agent hydrogen can be admixed in the middle of the channel. By dissociation and charge exchange a beam of excited species, radicals and ions $\left(A r, C, H, C_{x} H_{y}\right)$ is created, expanding out of the end of the arc channel (the nozzle). The particles are accelerated to supersonic velocities $(\sim 4000 \mathrm{~m} / \mathrm{s})$, pass through a shock and are transported further towards a substrate at subsonic velocities $(\sim 1000-1500 \mathrm{~m} / \mathrm{s})$. A typical value for the chamber pressure is $10^{2} \mathrm{~Pa}$; in this case the shock occurs at about $4 \mathrm{~cm}$ from the nozzle. Beyond the shock, the total energy of the species decreases to typically about $0.5 \mathrm{eV}$. A typical value for the carbon ion flux is $10^{19} / \mathrm{s}$.

e total transport time of all particles is relatively small (in the order of $10^{-4} \mathrm{~s}$ ), which minimizes the loss of ionization by three particle recombination. More details on the reactor and the cascaded arc can be found elsewhere [2, 3, 4].

As substrates, $10 \mathrm{~mm}$ discs (thickness $5 \mathrm{~mm}$ ) of carbon fiber composite (CFC, Dunlop DMS 678) with the fiber planes parallel to the surface normal and stainless steel (type AISI $316 \mathrm{Ti}$ ) were used. The CFC substrates were baked in vacuum on a temperature of $200^{\circ} \mathrm{C}$ during 24 hours. On a movable stainless steel support a batch of 5 substrates could be mounted. The nozzle-substrate distance was in general $5 \mathrm{~cm}$, resulting in substrate temperatures of about $1000^{\circ} \mathrm{C}$. Substrate temperatures were measured with an optical pyrometer (type Chino IR-AHIS). Deposition times were in the order of 20 minutes. Thicknesses and growth rates were estimated by weight change measurements.

\section{DEPOSITION PARAMETERS AND STRUCTURE OF THE COATINGS}

The properties of the deposited material were studied in relation with the following principal deposition conditions (see also [4]):

1. The hydrogen admixture flow rate $\{\mathrm{H}\}$.

2. The inverse energy factor $\mathrm{Q}=\left\{\mathrm{C}_{\mathrm{flow}}\right\} /\left(\left\{\mathrm{Ar}_{\text {flow }}\right\}^{*} \mathrm{P}_{\text {arc }}\right)\left[\mathrm{W}^{-1}\right]$

3. The substrate temperature $\mathrm{T}_{\mathrm{s}}\left[{ }^{\circ} \mathrm{C}\right]$

A clear relation between morphology, Raman spectrum and deposition environment is displayed in figure 3 through 5 . In figure 3 and 4 the change of the typical cauliflower morphology of amorphous graphite to a structure with distinct foliates of crystalline graphite is shown, deposited without and with a substantial hydrogen admixture respectively. In the Raman spectra sequence of figure 5 , the decrease of the defective graphite $1355 \mathrm{~cm}^{-1} \mathrm{D}$ peak with respect to the $1581 \mathrm{~cm}^{-1}$ $G$ peak with increasing hydrogen admixture is striking. All other reactor parameters were kept approximately the same. The crystallite size, estimated from the intensity ratio of the $D$ and the $G$ peak $I_{d} / I_{g}$ [6], increases from $\sim 3$ to $30 \mathrm{~nm}$. Figure 4 shows that the real graphite packet size is obviously much larger. In figure 6 the effect of the increasing hydrogen admixture is quantitatively demonstrated. Considering the influence of the energy factor $Q$ it appeared that particularly for low $\left(<3.10^{-6} \mathrm{~W}^{-1}\right)$ as for high values of $Q\left(>60.10^{-6} W^{-1}\right)$ good quality graphite can be produced. The substrate temperature was raised to values in the range of -800 to $1400^{\circ} \mathrm{C}$ in order to avoid hydrogen incorporation in the layer and to favor crystallization (see e.g. [7]). Up to now, within this range no variation of coating properties with temperature has been determined.

The deposition rates decrease with increasing hydrogen admixtures generally. In order to control the relative etching effect by the hydrogen radicals, the nozzle to 


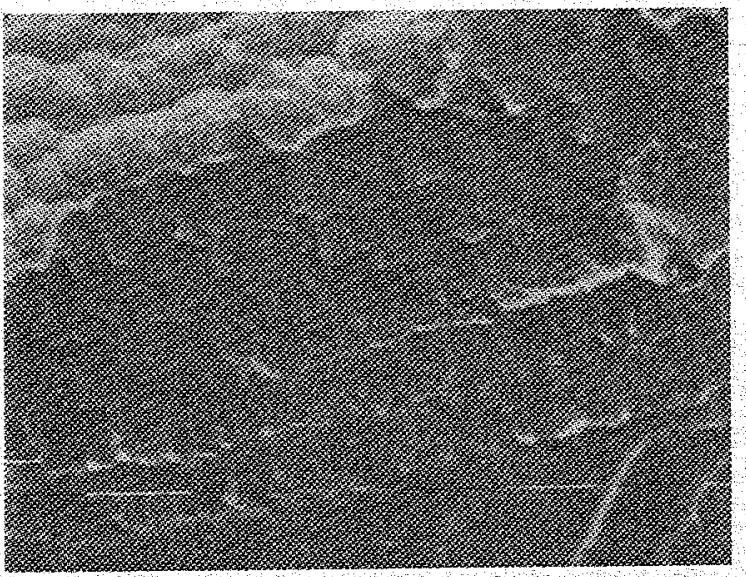

Figure 3. SEM micrograph of a typical amorphous graphite coating (side view). 1 bar $=100 \mu \mathrm{m}$.

substrate distance was adjusted to small values (some $\mathrm{cms}$ ). It is not certain whether the relation of crystallinity with growth rate would be implicit; in one trial a graphite with an $I_{d} / I_{g}$ ratio of 0.25 was produced at a high rate of $78 \mathrm{~nm} / \mathrm{s}$.

Macroscopically, the layers deposited with low amounts of $\mathrm{C}_{2} \mathrm{H}_{2}$ or with $\mathrm{CH}_{4}$, consisted of a black, soothy material with a poor coherence. The adhesion of these layers as a whole to the substrates was weak. With a large amount of $\mathrm{C}_{2} \mathrm{H}_{2}$ injection (high $Q$ factor) and without hydrogen admixture, hard grey coherent layers of amorphous graphite were produced. The crystalline layers produced with hydrogen admixture are more porous (estimated density in the order of $1 \mathrm{~g} / \mathrm{cm}^{3}$ ). In general the adhesion of the crystalline materials to CFC is very good, to steel moderate.

The results of the third and highly relevant diagnostic, the thermal shock testing, can be quantified by the parameters erosion threshold and erosion depth. The first is the lower limit of the laser pulse power at which erosion starts to occur, the latter the depth of the crater caused by a $3 \mathrm{MJ} / \mathrm{m}^{2}$ energy dump (in 10 $\mathrm{ms}$ ). Figure 7 shows that the erosion resistance increases with increasing hydrogen admixture, consistent with the

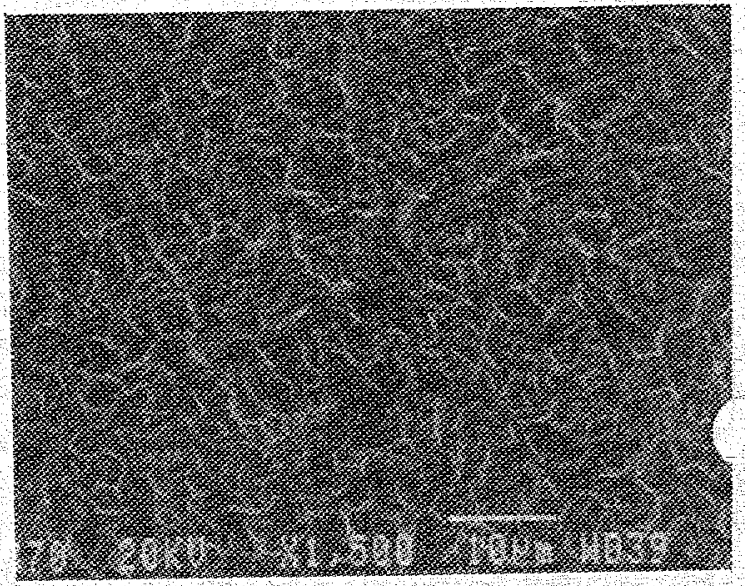

Figure 4. SEM micrograph of a typical crystalline graphite coating (top view), deposited with a hydrogen admixture of $20 \mathrm{cc} / \mathrm{s}, 1 \mathrm{bar}=10 \mu \mathrm{m}$.

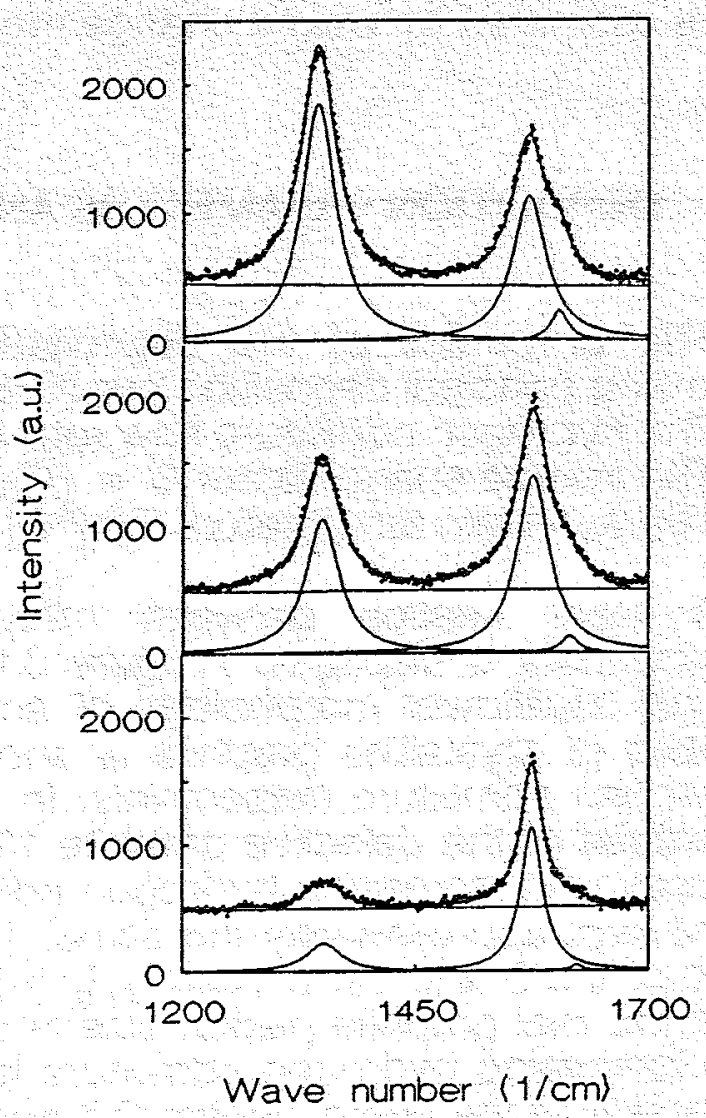

Figure 5. Effect of increasing hydrogen admixture on Raman spectra. From top to bottom $\mathrm{H}_{2}$ admixtures 5,10 and 20 $\mathrm{cc} / \mathrm{s}$ resp; growth rates 21,12 and 13 $\mathrm{nm} / \mathrm{s} . \mathrm{Q} \simeq 7.10^{-6} \mathrm{~W}^{-1}, T_{\mathrm{pyro}} \simeq 840^{\circ} \mathrm{C}$. 
results of the Raman analysis (figure 6). The damage after a $3 \mathrm{MJ} / \mathrm{m}^{2}$ thermal shock was studied by SEM. It appeared that the amorphous graphite coatings were fully shattered or substantially eroded. An example of the latter is shown in figure 8. The crystalline coatings mostly remained in place, with various degrees of erosion damage, and in some cases cracks. A crystalline coating with a good resistance to the shock is shown in figure 9 . Only minor erosion occurred, obviously together with surface modification. The porosity of the coatings may be advantageous in preventing cracking.

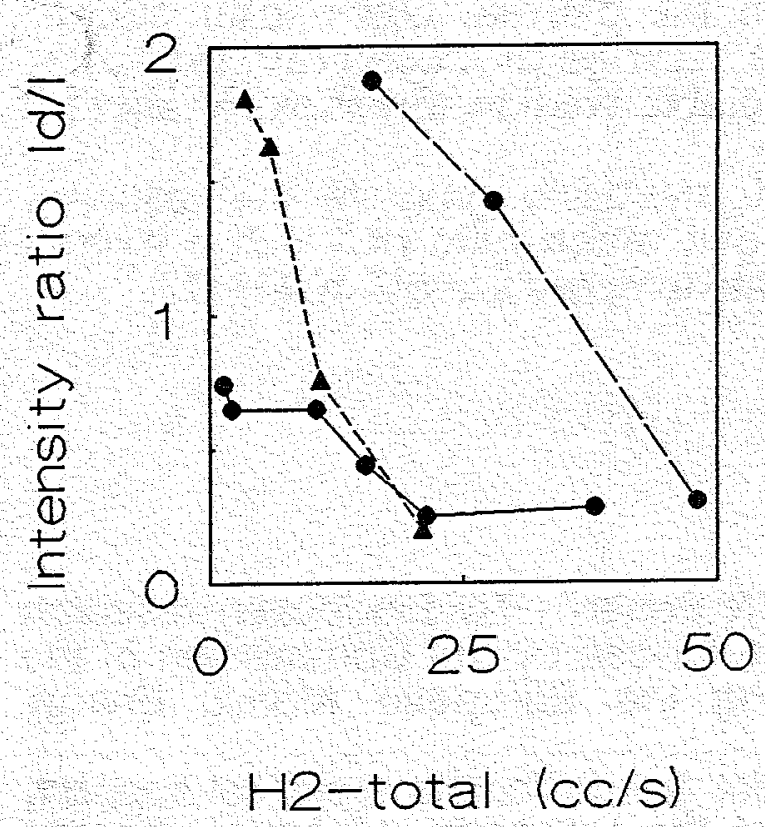

Figure 6. Raman peak intensity ratio $I_{1} \mathrm{I}_{\mathrm{g}}$ vs. total $\mathrm{H}_{2}$ input. $\bullet-, \rightarrow \mathrm{CFC},-\mathrm{-}$ Steel;; $Q \simeq 60,3$ and $7.10^{-6} \mathrm{~W}^{-1}$ resp.

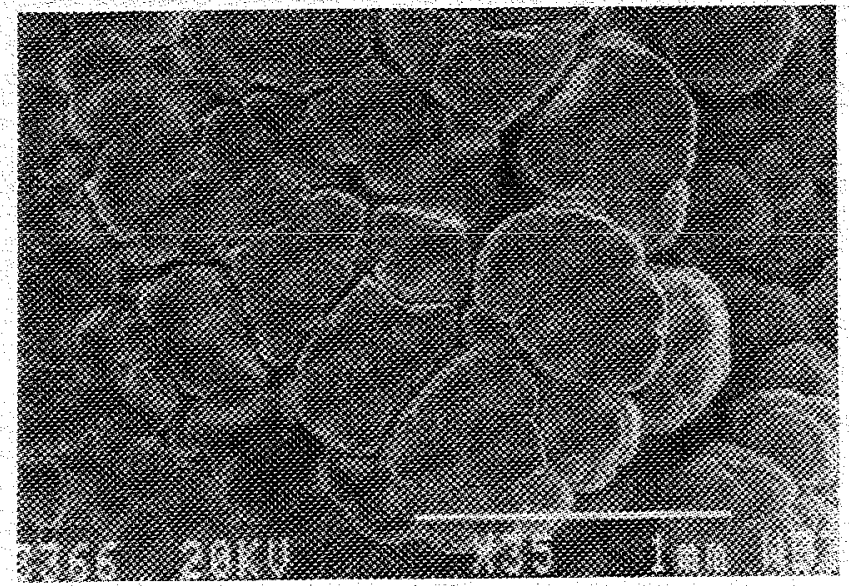

Figure 8. SEM micrograph of an amorphous graphite coating after a 3 $\mathrm{MJ} / \mathrm{m}^{2}$ thermal shock. Thickness before shock $377 \mu \mathrm{m}$, erosion depth $145 \mu \mathrm{m} .1 \mathrm{bar}=1 \mathrm{~mm}$

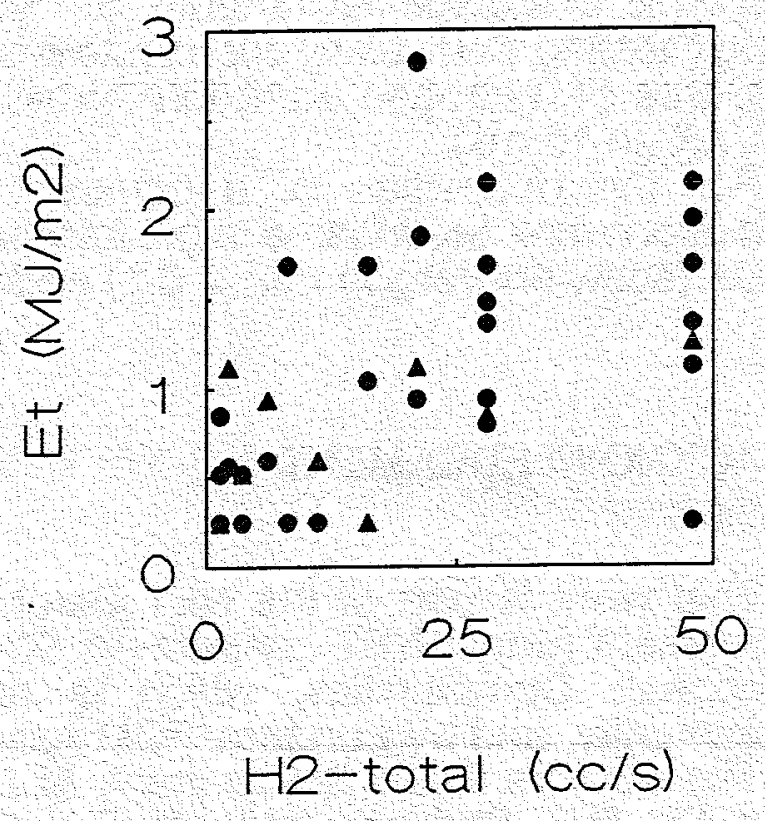

Figure 7 Erosion threshold Et vs. total $\mathrm{H}_{2}$ input (various other deposition parameters), • CFC, \& Steel.

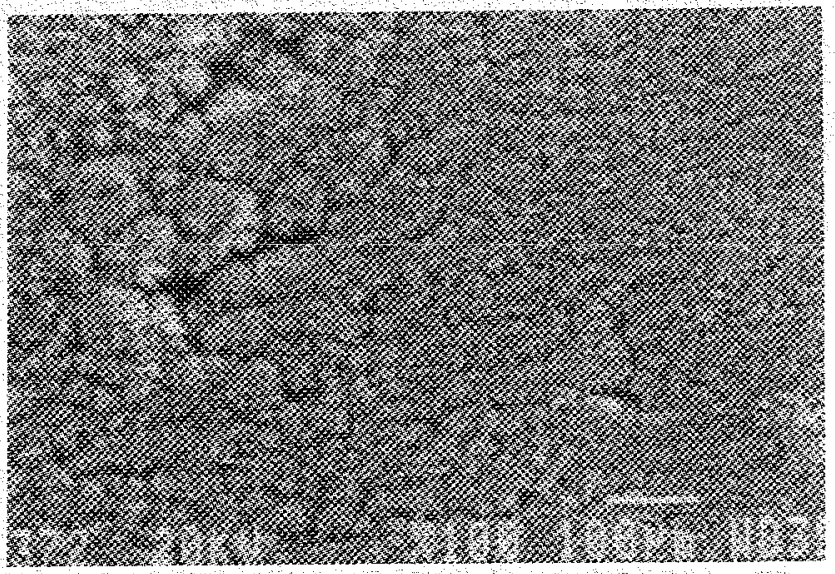

Figure 9. SEM micrograph of a crystalline graphite coating after a 3 $\mathrm{MJ} / \mathrm{m}^{2}$ thermal shock. Thickness before shock $57 \mu \mathrm{m}$, after shock 25 $\mu \mathrm{m} .1 \mathrm{bar}=100 \mu \mathrm{m}$. 


\section{CONCLUSIONS}

Coatings of amorphous graphite with a thickness of hundreds of microns and crystalline coatings with a thickness of tens of microns have been deposited in a few tens of minutes, both on areas of several $\mathrm{cm}^{2}$.

Relations between deposited material and the deposition conditions have been established. The three diagnostics SEM, Raman spectroscopy and laser thermal shock testing give consistent results: The crystallinity of the graphite is improved by admixing a substantial amount of hydrogen in the plasma. Upon laser ther shock testing particularly the crystalline graphite coatings produced with increas. amounts of hydrogen admixture show an acceptable erosion threshold of about 2 $\mathrm{MJ} / \mathrm{m}^{2}$ (in $10 \mathrm{~ms}$ ).

For the deposition of a coherent layer of crystalline graphite the following conditions are essential: a high (atomic) hydrogen/argon ratio of $\sim 0.8$, a high Q value (acetylene/argon ratio -0.1 ) and a substrate temperature of $-1000^{\circ} \mathrm{C}$.

\section{ACKNOWLEDGEMENT}

This work is part of the NET Garching - ECN Petten - TU Eindhoven research agreement (under NET contract-no. 90-237). It is funded by the Commission of the European Communities, which is representing the European Atomic Energy Community, and by Euratom/FOM Association.

The authors would like to thank M.J.F. van der Sande for the technical support, and Dr. D.J. Stufkens and Mr. T.L. Snoeck of the University of Amsterdam for measuring the Raman spectra.

\section{REFERENCES}

1. R.D. Watson (ed.), "ITER Divertor Engineering Design", ITER-TN-PC-8-9-1, ITER Document, p. 51 (Oct. 1989).

2. G.M.W. Kroesen, D.C. Schram and M.J.F. van de Sande, Plasma Chem. and Plasma Proc., 10, 1, p. 49 (1990).

3. P.K. Bachmann, H. Lydtin, D.U. Wiechert, J.J. Beulens, G.M.W. Kroesen, D.C. Schram, Proc. 3rd Conf. on Surface Modification Technologies, p. 69, Neuchatel, Switzerland (sept. 1989).

4. A.J.M. Buuron, J.J. Beulens, M.J.F. van de Sande and D.C. Schram, Fusion Technology (july 1991), in press.

5. J.G. van der Laan, H.T. Klippel, J. Bakker, R.C.L. van der Stad, paper presented at the 4th International Conference on Fusion Reactor Materials, Kyoto, December 4-8 1989, to be published in the Journal of Nuclear Materials.

6. F. Tuinstra and J.L. Koenig, J. Chem. Phys., 53, p. 1126 (1970).

7. W. Zhu, C.A. Randall, A.R. Badzian, R. Messier, J. Vac. Sci. Technol. A7 (3), p. 2315, (May/Jun 1989).

8. Y Mitsuda, Y. Kojima, T. Yoshida, K.Akashi, J. Mat. Science 22, p 1557 (1987). 